\title{
Influence Of Balinese Local Culture-Based Organizational Culture On Funding Decisions And Financial Performance (A Study On Cooperatives In Denpasar)
}

\author{
I Made Suniastha Amerta, Agus Putra Mardika, and Ni Wayan Sitiari \\ \{info@warmadewa.ac.id\} \\ Universitas Warmadewa, Denpasar-Bali
}

\begin{abstract}
This study aims to identify the determinants of cooperation in Denpasar. Financial performance in this study is influenced by funding decisions and organizational culture. Culture that develops and is applied to organizations or companies can influence decisions taken by management or company owners related to the use of external funding sources that can affect financial performance. This study is a quantitative type survey method. The data are collected using questionnaires, interviews and documentation. The respondents of this study were 58 cooperative managers in Denpasar. Data analysis was performed using PLS (Partial Least Square). The results indicate that organizational culture has a positive and not significant influence on funding decisions, organizational culture has a positive and significant influence on financial performance and funding decisions have a negative and significant influence on financial performance. This study are expected to provide an understanding of how funding decisions is reflected in the amount of third party funds (savings and deposits), it means that the increasing number of third party funds will increase the value of cooperatives, if cooperative funds increase, cooperatives will easily increase lending to the community, increasing deposit rates, so that cooperatives in Denpasar city will grow rapidly.
\end{abstract}

Keywords: Menyama Braya, Decision of Funding, Financial Performance

\section{Introduction}

Cooperative is business entity established with members based on family principles. Cooperatives build and develop the potential and economic of the members and general public and increase economic welfare based on principle of family. Business activities carried out by cooperatives include trade, financial services, credit services, marketing activities, or other activities. The purpose of cooperatives is to improve the welfare of members and community, as well as an integral part of a democratic and just national economic order (Cooperatives Office, 2012).

Ministry of Cooperatives and SMEs (2018) states that the development of active cooperatives from 2013 to 2017 increases by 4.6 percent every year, while inactive 
cooperatives increases from year to year by $12.8 \%$. Several studies on cooperatives show that the existence of cooperatives is not only beneficial to members of cooperatives but also has a role in the absorption of labor. This following is the number of developments of SHU or surplus of cooperative in Denpasar city.

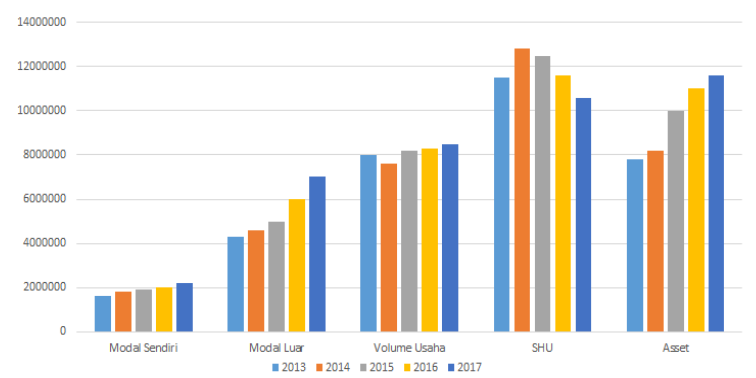

Fig.1. Development of SHU Cooperatives in Denpasar City

Based on table 1, that in 2013 - 2017 the development of the number of SHU cooperatives in Denpasar tended to decline. This reflects the cooperative's performance needs to be improved. cooperatives management must be more professional, supported by qualified human resources and able to compete between cooperatives and other businesses.

Law No.25 of 1992 regulates cooperatives as business entities, thus cooperatives remain compliant with company rules and applicable economic principles. Therefore, cooperatives must be able to generate profits in developing their organization and business. The success of the cooperatives in carrying out their business can be seen from the financial statements. cooperative financial statements are a very important tool for obtaining information relating to the financial position and results of cooperative activities.

Financial performance can be measured by efficiency ratio, which is the ratio between income and expenditure. The factors that influence financial performance are funding decisions because they reflect the proportion of the use of corporate funding sources [1]. In addition, [2] the use of capital can improve financial performance if the use of capital can increase profits. [3] funding decisions affect financial performance.

A culture that develops and is applied to an organization or company ... will ultimately affect financial performance [1]. The organizational culture in this study is an organizational culture based on Balinese local culture, that is equalization concept. Braya culture has a valid and reliable meaning that reflects Balinese local culture [4]. Organizational culture extracted from Balinese local wisdom (menyama braya) which is an intangible resource that can improve the financial performance of cooperatives in Denpasar. Menyama braya is a relationship of brotherhood that is actualized in the form of ngayah, mutual cooperation, nguopin [5]. The attitude of working together, helping each other, prioritizing brotherhood are shared values that are consistent with the concept of equaly. A number of latest related studies are conducted to differentiate this present study with another previous studies. The first latest related study was about the Effect of Organizational Culture on Financial Performance through Manager Behavior on Environmental Management Issues as its Intervening Variable. The purpose of this study is to determine whether there is an effect of organizational culture on corporate financial performance through management behavior on environmental issues. The results of this study showed that organizational culture has a significant and positive effect on the financial performance of limited liability companies in Surabaya and surrounding areas (Djuanda \& Tarigan, 2016). The second latest related research was studied by Limbunan $\&$ Tarigan (2016). The study aimed to examine the influence of Organization Culture on 
Financial Performance using the owner's behavior on the issue of environmental management as an intervening variable. The result of the study was the organization culture had positive effect on financial performance with the variable behavior of the owner on the issues of environmental management as the intervening variable. Reni (2018) carried out the study about the influence of organizational culture on the performance of Nagari aparatures in Nagari financial management. The result in the study showed that organization culture variable, both simultaneously and partially significantly influence the Nagari financial management in Tanah Datar Regency. Taking into account the latest related research, therefore, this present research aims to identify the determinants of cooperation in Denpasar.

Based on the problem framework aforementioned, the independent variables in this study were organizational culture, funding decisions and financial performance. Therefore, it can be drafted a concept that explained the relationship between variables in this study. The research model is presented at fig. 1 .

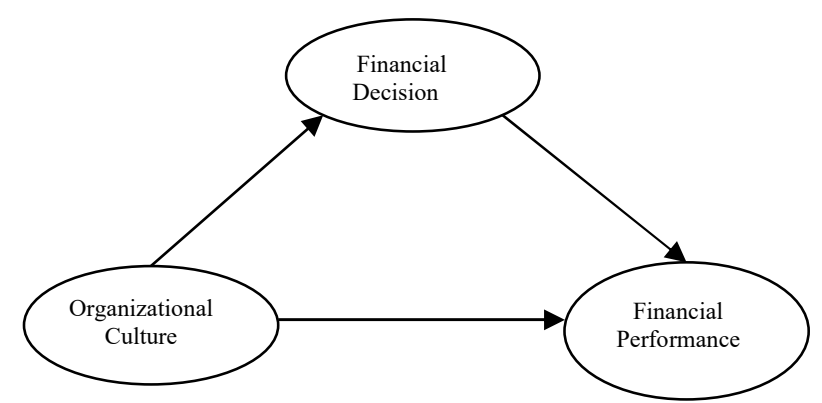

Fig. 2. Framework

\section{METHOD}

This research uses a quantitative type survey method. This research is also a causal study that tests the influence of variables. The object of this research is all cooperatives registered in cooperatives office dan office of small and medium enterprise (OSME) in Denpasar. Instruments of data collection uses questionnaires, interviews and documentation. The population used in this study amounted to 141 cooperatives. Slovin Formula can be used to determine the sample size of the population. In accordance with the Slovin Formula the number of sample respondents was obtained by 58 cooperatives. The method to determine respondents is a simple random sampling without recovery. This study uses PLS to analyze the relationships between variables. 


\section{Result and Discussion}

Table 1. Outer Loading Value Results Estimated After Model Reconstruction

\begin{tabular}{cccccc}
\hline Construct & Indikator & $\begin{array}{c}\text { Outer } \\
\text { Loading }\end{array}$ & $\begin{array}{c}\text { Alpha } \\
\text { Cronbach's }\end{array}$ & CR & AVE \\
\hline ORGANIZATIONAL & $\mathbf{( X 1 . 5 )}$ & 0,90 & 0,77 & 0,72 & 0,57 \\
CULTURE & $\mathbf{( X 1 . 6 )}$ & 0,58 & & & \\
DECISION OF FUNDING & $\mathbf{( X 2 . 1 )}$ & 0,93 & 0,79 & 0,77 & 0,63 \\
& $\mathbf{( X 2 . 3 )}$ & 0,63 & & & \\
FINANCIAL PERFORMANCE & $\mathbf{( Y 1 . 1 )}$ & 1,12 & 0,76 & 0,99 & 0,99 \\
& $\mathbf{( Y 1 . 4 )}$ & 0,84 & & & \\
\hline
\end{tabular}

Source : Data processed 2019

Table 2, all these indicators have met the valid requirements based on discriminant validity conditions, which have the value of outer loading $>0.50$. From the test results in table 2 , shows that all indicators, reflected by each construct examined, have cronbachs Alpha values greater than 0.70 which means that all indicators measured in this study are reliable.

Based on Table 2 shows that the AVE value of each construct has a value above 0.50 with the index value of $\sqrt{ } \mathrm{AVE}$ each construct greater than the correlation value between constructs, thus it has been declared valid based on discriminant validity criteria. While the composite reliability value of each construct has shown a value greater than 0.70 thus it meets reliable requirements based on composite reliability criteria. In terms of the value of Cronbach Alpha all constructs show values greater than 0.70 , thus they meet valid requirements. And results can be seen in Fig. 2

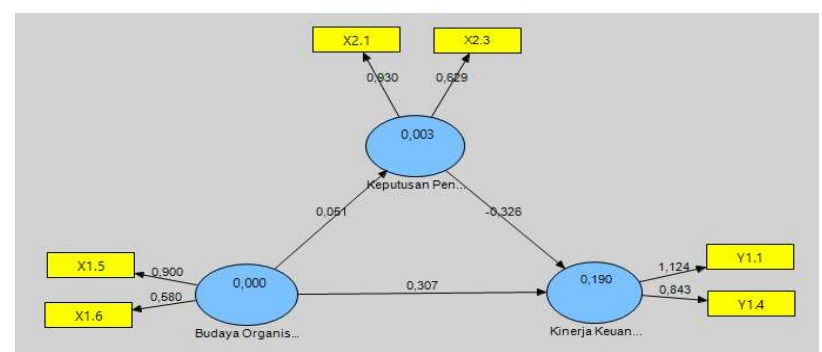

Fig. 3. Outer Loading and Path Analysis of estimation results

Table 2. Evaluation of Inner Structural Model

\begin{tabular}{cc}
\hline Construct & R Square \\
\hline Organizational Culture & \\
Decision of Funding & 0,003 \\
Financial Performance & 0,190 \\
\hline
\end{tabular}

Source : Data Processed 2019

Table 3 shows that the R Square value of funding decisions is 0.003 , then the model includes the criteria of a weak model meaning that organizational culture variations can explain variations in funding decisions by $0.3 \%$ percent and the remaining $99.07 \%$ percent is explained by variations in other variables outside the model. While financial performance has a r-square value of 0.190 or including a weak model, meaning that organizational culture variation and funding decisions are able to explain variations in financial performance, namely $19 \%$ percent and $81 \%$ explained by variations outside the model. 
Table 4. Evaluation Goodness of Fit

\begin{tabular}{ccc}
\hline Konstruk & R Square & Communality \\
\hline ORGANIZATIONAL CULTURE & & 0,93 \\
\hline DECISION OF FUNDING & 0,003 & 0,92 \\
\hline FINANCIAL PERFORMANCE & 0,190 & 0,96 \\
\hline Average & 0,10 & 0,93 \\
\hline
\end{tabular}

Source : Data processed 2019

Based on Table 4, calculations with GoF show an average value of R2 of 0.37 while the average Communality is 0.89 , then the value of GoF is $\sqrt{ }$ AR2 $*$ Average Communality $=\sqrt{ }$ $0.10 * 0.93=\sqrt{ } 0.09=0.30$, which means that the global model in this study is large predictive.

Table 5. Path Analysis and Statistics

\begin{tabular}{cccccc}
\hline Construct & $\begin{array}{c}\text { Original } \\
\text { Sample (O) }\end{array}$ & $\begin{array}{c}\text { Sample } \\
\text { Mean (M) }\end{array}$ & $\begin{array}{c}\text { Standard } \\
\text { Deviation } \\
\text { (STDEV) }\end{array}$ & $\begin{array}{c}\text { Standard } \\
\text { Error } \\
\text { (STERR) }\end{array}$ & $\begin{array}{c}\text { T Statistics } \\
\text { (|O/STERR|) }\end{array}$ \\
\hline $\begin{array}{c}\text { Organizational Culture -> } \\
\text { Funding of Decisions }\end{array}$ & 0,05 & 0,07 & 0,22 & 0,22 & 0,23 \\
\hline $\begin{array}{c}\text { Organizational Culture -> } \\
\text { Financial Performance }\end{array}$ & 0,31 & 0,30 & 0,10 & 0,10 & 3,02 \\
\hline $\begin{array}{c}\text { Funding Decision -> } \\
\text { Financial Performance }\end{array}$ & $-0,33$ & $-0,27$ & 0,18 & 0,18 & 1,80 \\
\hline
\end{tabular}

Data processed, 2019

Based on table 5 relationship between organizational culture and funding decisions is not significant, relationship between organizational culture and financial performance is significant and the relationship between funding decisions and financial performance is negative and not significant.

\subsection{Influence of Organizational Culture on Funding Decisions at Cooperatives in Denpasar}

The influence of organizational culture on funding decisions at cooperatives in Denpasar; is insignificant effect. The insignificant relationship explains that the application of the values contained in Bali's local culture has not been able to increase funding decisions on cooperatives in Denpasar City, the cooperative is easier to give credit to the community because it has established a longer relationship, so that a trust has been formed.

The concept of cultural sharing is a social system of a member of the organization that can be described as a number of social relations and social relations with basic assumptions and beliefs along with members of the organization. Organizations that have a strong network of relations will influence the behavior of funding decisions with increasing trust held by the community, then the credit channeled by cooperatives also increases.

Based on the facts in the field that cooperatives in Denpasar are less interested in channeling and collecting credit to/from the community, compared to other financial institutions, which use the ball picking system. [6] the length of time the relationship with the lender has an effect on the small amount of credit and the credit period. So that the increase in credit channeled is closely related to looking for relationships because of mutual need.

The results of this study contradict the results of previous studies [7] examined in companies in Egypt. The researcher found that organizational culture has a positive and significant influence on funding decisions. With the application of organizational culture to 
create a decision of funding owned by companies. The higher the organizational culture of a company, the funding decisions will also increase. Organizational culture reflected in individualism and fatalism can increase the company's long-term and short-term debt.

[8], [1], [9] found organizational culture has a positive and significant effect on funding decisions. This means that the application of an increasingly good organizational culture will be able to increase funding decisions.

\subsection{Influence of Organizational Culture on Financial Performance at Cooperatives in Denpasar}

The influence of organizational culture on financial performance at cooperatives in Denpasar, has a significant effect. This shows that the more application of the culture of equalization held by cooperative managers increases, the more it will improve the financial performance of cooperative. By establishing good cooperation between one cooperative manager and another cooperative manager, information in the field shows that the growth of cooperatives has a significant increase in the number of assets.

This is in accordance with the reality that cooperatives in Denpasar City have more than one thousand members. It indicates that the cooperative has increased the number of its members. The cooperative financial performance will increase, due to the fulfillment of the organization's cultural characteristics. The results of this study are in line with [10] on property companies that were active in 2013 found that organizational culture had a positive and significant effect on the company's financial performance. Organizational culture based on local Balinese culture can improve the company financial performance and drive company profits. Whereas research conducted of some studies found that organizational culture has a positive and significant effect on financial performance. The better values of innovation and courage to take risks, attention to detail, results-oriented activities, human-oriented organizations, team-oriented, managerial aggressiveness and organizational stability, lead to increasingly cooperative financial performance [11] and [12].

\subsection{Influence of Funding Decisions on Financial Performance at Cooperatives in Denpasar}

The influence of funding decisions and financial performance is negative and not significant. The Negative relationship indicates that lower funding decisions held by cooperative managers in Denpasar will affect the improvement of financial performance. Decreasing the number of third parties funds (savings and deposits) in cooperatives will increase the value of cooperatives, it shows that cooperatives in Denpasar have abundant funds from members.

The right strategy applied for cooperatives in Denpasar in relation to increasing funding decisions is a strategy to find a wider market share for existing products through more active marketing efforts and product development strategies, namely strategies that seek to increase revenue by improving products that existing or developing new products.

The results of the study support the results of previous studies [13] that funding decisions had a negative and significant effect on financial performance. This happens because the increase in debt both short-term and long-term debt will increase total assets and equity, which will cause profitability to decrease. The smaller the level of debt used, the higher the return on company assets, stock returns, and return on equity.

The results of this study contradict the results of previous studies [8] and [3] that funding decisions have a positive and significant effect on financial performance. 


\section{Conclusion}

Based on the result and discussion above, the conclusion of this study that can be made are:

1) The influence between organizational culture on funding decisions shows positive and insignificant results. This means that the application of Balinese local cultural values has not been able to increase funding decisions on cooperatives in Denpasar. By establishing good cooperation between one cooperative manager and another cooperative manager, it has not been able to increase the amount of third parties funds (savings and deposits).

2) The influence between organizational culture on financial performance shows positive and significant results. The increasing application of the same culture of equalization owned by cooperative managers, has increasingly enhanced the financial performance of cooperatives. By establishing good cooperation between one cooperative manager and another cooperative manager, information in the field shows that the growth of cooperatives has a significant increase in the number of assets.

3) The influence between funding decisions on financial performance shows negative and significant results. This means that lower funding decisions owned by cooperative managers in Denpasar will affect the improvement of financial performance. Decreasing the number of third parties funds (savings and deposits) in cooperatives will increase the value of cooperatives, it shows that cooperatives in Denpasar have abundant funds from members.

\section{References}

[1] N. L. P. Wiagustini, N. L. A. P. Ningsih, and L. G. S. Artini, "Budaya 'Catur Purusa Artha' dan Orientasi Kewirausahaan Sebagai Basis Keputusan Pendanaan dan Kinerja Keuangan,” pp. 27 $28,2017$.

[2] E. F. Brigham and P. R. Daves, Intermediate financial management, 9th ed., vol. 21, no. 3. 1989.

[3] N. Anggraini, "PENGARUH STRUKTUR MODAL TERHADAP KINERJA KEUANGAN PADA PERUSAHAAN FARMASI YANG TERDAFTAR DI BURSA EFEK INDONESIA PERIODE 2010-2014," vol. 4, no. 2, 2017.

[4] Sitiari, "Exploration of Bali's Cultural Values and Entrepreneurial Orientation in Relation to Cooperative Managers In Bali,” Eur. J. Bus. Manag., vol. 8, no. 2, pp. 158-169, 2016.

[5] I. G. Parimartha, "Karakter Bangsa dan Aktualisasinya dalam Kehidupan Masyarakat Bali," Forum Arkeol., vol. 25, no. 2, 2012.

[6] J. C. Brau, "Do Banks Price Owner-Manager Agency Costs? An Examination of Small Business Borrowing," J. Small Bus. Manag., vol. 40, no. 4, pp. 273-286, 2002.

[7] N. Erfan and K. Elgiziry, "The impact of managerial risk culture on the capital structure and the investment decision of corporations in Egypt,” Int. Res. J. Appl. Financ., vol. 7, no. 12, 2016.

[8] N. L. A. P. Ningsih, N. L. P. Wiagustini, L. G. S. Artini, and H. Rahyuda, "Organizational Culture, Decision of Funding and Financial Performance: An Evidence from Small and Medium Enterprises," Eur. J. Bus. Manag., vol. 7, no. 32, pp. 148-158-158, 2015.

[9] A. . Fleming, L. Petheram, and N. Stacey, "Australian indigenous women's seafood harvesting practices and prospects for integrating aquaculture," J. Enterprising Communities People Places Glob. Econ., vol. 9, no. 2, pp. 156-181, Jan. 2015.

[10] I. P. Astawa and P. Sudika, "The Impact of Local Culture on Financial Performance in Property Firms in Bali," Asia Pacific Manag. Bus. Appl., vol. 3, no. 2, pp. 106-115, 2014.

[11] Arifin, "PENGARUH BUDAYA ORGANISASI TERHADAP KINERJA PERUSAHAAN DAERAH AIR MINUM KABUPATEN BONE BOLANGO,” vol. 01, no. 02, 2014. 
[12] dan W. Ratnadi, Putra, "Budaya Organisasi, Orientasi Etika dan Kinerja Keuangan Koperasi," J. FEB ISSN 1978-6069, vol. 12, no. 1, pp. 96-111, 2017.

[13] A. K. Wardani and F. R. Dewi, "Analisis Struktur Modal terhadap Kinerja Keuangan Perusahaan Sektor Utama yang Terdaftar di Indeks LQ45 Bursa Efek Indonesia,” J. Manaj. dan Organ., vol. 6, no. 2, p. 134, 2016. 